\title{
AKTIVITAS KERJASAMA (COLLABORATION) MAHASISWA DALAM PEMBELAJARAN KOOPERATIF MAKE A MATCH MELALUI IMPLEMENTASI LESSON STUDY
}

\author{
Annajmi ${ }^{1}$ \\ Universitas Pasir Pengaraian \\ annajminajmi86@gmail.com
}

\begin{abstract}
ABSTRAK Penelitian ini dilaksanakan dengan tujuan untuk mengetahui aktivitas kerjasama mahasiswa dalam pembelajaran kooperatif make a match melalui kegiatan lesson study. Kegiatan Lesson Study (LS) ini dilaksanakan dalam dua siklus, yang terdiri dari tiga tahapan yaitu tahap plan (perencanaan), tahap do (pelaksanaan), tahap see (refleksi). Subjek penelitian ini adalah mahasiswa offering C angkatan 2018 Program Studi Pendidikan Matematika Universitas Negeri Malang. Data penelitian dikumpulkan menggunakan lembar observasi, rekaman video, dan hasil pekerjaan mahasiswa yang berupa lembar kerja mahasiswa. Hasil penelitian aktivitas kerjasama mahasiswa juga menunjukkan adanya aktivitas yang tidak mendukung proses pembelajaran kooperatif make a match, dimana adanya mahasiswa yang berdiskusi hal hal lain dalam kelompoknya, mahasiswa yang berdiskusi dengan kelompok lain, adanya mahasiswa yang mendominasi dalam diskusi kelompok, dan adanya mahasiswa yang belajar secara individu dalam kelompok, mahasiswa membuang waktu diskusi dengan saling bercanda dan tidak adanya pembagian tugas yang baik. Hasil kegiatan lesson study yang menunjukkan aktivitas kerjasama mahasiswa yang mendukung proses pembelajaran kooperatif make a match, dimana adanya antusiasme mahasiswa dalam bekerja sama, mahasiswa fokus berdiskusi dengan kelompoknya sendiri, dominasi mahasiswa dalam kelompok menurun, mahasiswa saling membantu teman dalam satu kelompoknya dan mahasiswa memanfaatkan waktu dengan baik. Berdasarkan hasil penelitian ini dapat disimpulkan bahwa aktivitas kerjasama mahasiswa dalam pembelajaran kooperatif make a match dapat dibantu dengan memberikan perhatian khusus kepada mahasiswa tertentu memberikan tugas untuk mampu dalam melakukan pemecahan masalah matematis, penjelasan prosedur dalam pembentukan kelompok, prosedur dalam berdiskusi, pemanfaatan media, memberikan tugas dalam diskusi yang lebih banyak dari waktu yang tersedia.
\end{abstract}

Kata-kata Kunci : lesson study, proses pembelajaran matematika, pembelajaran kooperatif, make a match, aktivitas kerjasama.

\section{PENDAHULUAN}

Proses pembelajaran merupakan bagian penting dari proses pendidikan, dimana melalui proses pembelajaran akan memberikan pengetahuan kepada mahasiswa. Kemampuan mengelola pembelajaran merupakan kunci keberhasil proses pembelajaran agar terwujudnya pembelajaran yang efektif dan menyenangkan bagi mahasiswa. Sutikno (2011) menyatakan bahwa 
pembelajaran efektif merupakan pembelajaran yang memfasilitasi pelajar untuk belajar dengan mudah, menyenangkan dan dapat mencapai tujuan pembelajaran. Selain itu Anthony dan Walshaw (2009), Kennedy, dkk (2008) dan Slavin (2006) menyatakan hal yang sama yaitu seorang pengajar harus memiliki kemampuan akademik serta mengelola pembelajaran dengan baik. Kemampuan akademik dan mengelola pembelajaran yang baik akan sangat mendukung seorang dosen dalam melaksanakan proses pembelajaran yang efektif dan menyenangkan, sehingga tercapainya tujuan pembelajaran. Kemampuan mengelola pembelajaran yang baik juga akan bermanfaat bagi dosen dalam memfasilitasi pelaksanaan perkuliahan dengan strategi pembelaajran yang inovatif dan menyenangkan, sehingga dapat mengembangkan kemampuan kerjasama mahasiswa dalam proses pembelajaran. Hamalik, (1999:138-139) menjelaskan bahwa pelaksanaan proses pembelajaran dititikberatkan pada keaktifan siswa belajar dan keaktifan guru atau dosen menciptakan lingkungan belajar yang serasi dan menantang.

Proses pembelajaran yang dilaksanakan harus dapat mengarahkan mahasiswa untuk bisa aktif bekerjasama dengan baik, khususnya dalam pembelajaran matematika. Pembelajaran matematika memiliki materi yang bersifat abstrak yang memerlukan kemampuan berpikir kritis untuk bisa menganalisis konsep konsep yang ada pada setiap topik pembahasannya. Berkaitan dengan itu diperlukan suatu kerjasama diantara mahasiswa untuk mampu menyelesaikan permasalahan matematis pada setiap topik yang dibahas. Pembelajaran yang dilaksanakan pada topik topik matematika seperti geometri, aljabar, kalkulus dan analisis sering kali hingga saat ini dilaksanakan masih berpusat pada dosen atau sering disebut juga teacher centered atau dikenal dengan pendekatan tradisional (Utami, dkk, $2011)$. Pembelajaran tersebut, menjadikan mahasiswa lebih banyak mendengar penjelasan dosen, dimana dosen sebagai individu yang lebih aktif dalam mengajar.

Pembelajaran yang dilaksanakan demikian, akan mengurangi aktivitas mahasiswa dalam bekerjasama serta kurangnya interaksi antara mahasiswa, yang berakibat pada pasifnya mahasiswa dalam pembelajaran. Selain itu juga akan berdampak pada kemampuan interaksi sosial mahasiswa dengan orang lain, bahkan sesama mahasiswa juga yang cenderung rendah. Hal ini dapat dilihat ketika mereka bergaul baik di dalam maupun di luar kelas. Mahasiswa lebih cenderung berinteraksi dan bekerjasama dengan teman satu grupnya saja yang mempunyai karakteristik sama, termasuk ketika diberikan tugas. Mereka akan cederung untuk mengerjakan tugas bersama mahasiswa yang karakteristiknya sama, dan melakukan kerjasama dengan maksimal, namun ketika bekerjasama dengan teman yang lain, mereka lebih sering hanya menerima keputusan satu orang saja, bahkan tidak jarang dengan menyerahkan pekerjaan tersebut kepada satu orang saja. Hal ini dikhawatirkan akan memberikan dampak pada kebiasaan mahasiswa ketika mereka praktek langsung atau berada pada dunia kerja sebagai guru, juga akan melaksanakan hal yang sama dalam proses pembelajaran matematika yang mereka lakukan di kelas kelas mereka pada saat menjadi guru matematika di 
sekolah sekolah. Kenyataan lainnya yang terjadi adalah mahasiswa lebih terbiasa dengan belajar individu memanfaatkan teknologi dan fasilitas lainnya yang tersedia, sehingga ketiga berdiskusi kelompok mereka lebih senang bekerja sendiri dan didominasi oleh satu mahasiswa tanpa melibatkan semua anggota kelompok. Ketika diberikan tugas kelompok mereka lebih suka satu kelompok dengan teman teman dekat dalam kehidupan sehari hari yang memiliki karakteristik yang sama. Hal ini menunjukkan bahwa tanggung jawab mereka terhadap tugas-tugas mereka masih rendah. Keadaan seperti ini juga terlihat pada mahasiswa offering C angkatan 2018 program studi Pendidikan Matematika Universitas Negeri Malang. Stein (2004) menyatakan bahwa tanggung jawab ini merupakan bagian dari unsur kerjasama yang akan memberikan dampak positif berupa kepuasan dari pelakunya dan akan menjadi hal biasa dalam menghadapi masalah yang menjengkelkan ketika berhadapan dengan banyak orang. Purwadarminta (2007) menyatakan bahwa kerjasama merupakan pekerjaan yang dilakukan oleh suatu kelompok sehingga terjalin hubungan erat antar tugas anggota kelompoknya. Slavin (2012) menyatakan bahwa kerjasama adalah bekerja bersama untuk mencapai tujuan yang diinginkan bersama. Hal ini berarti kerjasama merupakan melakukan suatu pekerjaan yang diselesaikan secara bersama untuk memperoleh suatu tujuan yang ingin dicapai. Kerjasama (collaboration) sangat diperlukan dalam pembelajaran matematika untuk mampu memahami konsep konsep matematika yang bersifat abstrak. Kerjasama memungkinkan mahasiswa untuk saling membantu dalam mengerjakan tugas sehingga hasil yang didapatkan dapat lebih maksimal. Davis \& Newstrom (1996) bahwa kerjasama melibatkan mental dan emosional orang di dalam situasi kelompok yang mendorong mereka untuk memberikan kontribusi dan tanggung jawab dalam mencapai tujuan kelompok.

Hopkins (2011) mengemukakan bahwa salah satu cara yang dapat digunakan untuk mengetahui bahwa mahasiswa benar-benar melakukan kerjasama yaitu dengan membentuk kelompok-kelompok. Barkley (2012) menyatakan bahwa jika pengajar menginginkan peserta didiknya untuk bekerja sama menyelesaikan tugas bersama, berbagi informasi, dan saling mendukung maka pembelajaran kooperatif lazim untuk dipraktekkan di dalam kelas.

Pembelajaran kooperatif make a match merupakan salah satu jenis model yang ada dalam model pembelajaran kooperatif, make a match merupakan salah satu pembelajaran yang dapat memberikan pembelajaran yang menyenangkan dan membuat siswa menjadi tertarik untuk belajar dan bisa berinteraksi sesama mahasiswa dalam berdiskusi. Wahab, (2007 : 59) menjelaskan bahwa model pembelajaran make and match adalah sistem pembelajaran yang mengutamakan penanaman kemampuan sosial terutama kemampuan bekerja sama, kemampuan berinteraksi disamping kemampuan berpikir cepat melalui permainan mencari pasangan dengan dibantu kartu. Model pembelajaran kooperatif tipe make a match cocok digunakan untuk meningkatkan kemampuan belajar siswa karena pada model pembelajaran ini siswa diberi kesempatan untuk berinteraksi dengan siswa lain, suasana belajar di kelas dapat diciptakan sebagai 
suasana permainan, ada kompetisi antar siswa untuk memecahkan masalah yang terkait dengan topik pelajaran matematika serta adanya penghargaan (reward), sehingga siswa dapat belajar matematika dalam suasana yang menyenangkan. Pembelajaran make a match atau mencari pasangan dikembangkan oleh Lorna Curran (1994). Model make and match melatih siswa untuk memiliki sikap sosial yang baik dan melatih kemampuan siswa dalam bekerja sama disamping melatih kecepatan berfikir siswa.

Berkaitan dengan itu Dosen sebagai bagian dari pembelajaran perlu memberikan pengetahuan yang dapat meningkatkan kerjasama mahasiswa dalam proses pembelajaran. Asnawati (2006) mengungkapkan bahwa adanya komunitas belajar akan merancang siswa untuk berdiskusi dengan kawannya, yang tentu saja akan meningkatkan aktivitas siswa, biasanya orang ingin dihargai pada komunitasnya, sehingga ia akan berusaha untuk mendapatkan penghargaan. Lesson study (LS) merupakan salah satu cara yang dapat digunakan untuk membentuk komunitas belajar yang bertujuan untuk mempersiapkan proses pembelajaran menggunakan pembelajaran kooperatif make a match, sehingga tujuan pembelajaran yang diharapkan dapat tercapai.

Lesson study digunakan untuk memperbaiki pembelajaran untuk meningkatkan kualitas pembelajaran seorang dosen yang dilakukan secara kolaborasi dalam melakukan perencanaan pembelajaran yang diakhir dnegan melakukan refleksi bersama. Garfield, (2006:1) menjelaskan bahwa lesson study adalah suatu proses sistematis yang digunakan oleh guru-guru Jepang untuk menguji keefektifan pengajarannya dalam rangka meningkat hasil pembelajaran. Stigler \& Hiebert (1999:120) juga menjelaskan bahwa lesson study digunakan untuk meningkatkan pengajaran di kelas. Pembelajaran yang dilaksanakan dengan Lesson study merupakan pembelaajan yang dilakukan dalam jangka waktu yang panjang, melakukan perbaikan yang terus menerus, berfokus pada pembelajaran mahasiswa, berfokus pada peningkatan proses pembelajaran, dan bersifat kolaboratif. Adapun tahapan Lesson study menurut Saito, dkk. (2005:26) adalah plan (perencanaan), do (pelaksanaan) dan see (refleksi). Tahap perencanaan (plan) bertujuan menghasilkan rancangan pembelajaran yang diyakini mampu membelajarkan peserta didik secara efektif dan membangkitkan partisipasi peserta didik dalam pembelajaran. Tahap pelaksanaan (do), dimaksudkan untuk menerapkan rancangan pembelajaran yang sudah direncanakan. Tahap pengamatan dan refleksi (see) dimaksudkan untuk menemukan kelebihan dan kekurangan pelaksanaan pembelajaran.

Berdasarkan uraian permasalahan yang telah diuraikan, maka pelaksanaan pembelajaran berbasis lesson study ini bertujuan untuk mendeskripsikan aktivitas kerjasama mahasiswa dalam pembelajaran kooperatif make a match.

\section{METODE PENELITIAN}

Penelitian ini adalah penelitian deskriptif kualitatif yang pembelajarannya dilakukan dalam tahapan tahapan lesson study. Penelitian ini dilaksanakan ketika mengikuti Program Magang Dosen 2018 Kementerian Riset Teknologi dan 
Pendidikan Tinggi di Universitas Negeri Malang. Adapun yang menjadi subjek penelitian ini adalah mahasiswa semester 1 (satu) Offering D Program Studi Pendidikan Matematika FMIPA Universitas Negeri Malang Tahun Akademik 2018/2019 pada bulan September 2018. Data penelitian yang dikumpulkan adalah data tentang aktivitas kerjasama mahasiswa dalam diskusi kelompok dan diskusi kelas. Adapun instrumen pengumpulan data yang digunakan adalah

1. Lembar Obervasi

Lembar obervasi disajikan dalam bentuk pertanyaan pertanyaan tentang kegiatan pembelajaran dan catatan catatan temuan temuan dalam belajar. Selanjutnya secara khusus untuk aktivitas kerjasama mahasiswa juga menggunakan menggunakan skala likert, yaitu:

Skor masing masing aspek 1 sampai dengan 4, berdasarkan skala likert, yaitu

- Skor 4 jika keempat indikator muncul

- Skor 3 jika tiga indikator muncul

- Skor 2 jika dua indikator muncul

- Skor 1 jika satu indikator muncul

Adapun indikator yang diamati untuk aktivitas kerjasama mahasiswa, yaitu

- mahasiswa melakukan diskusi dengan temannya

- bertanya kepada teman/menjawab pertanyaan teman

- membantu teman yang mengalami kesulitasn

- mengerjakan tugas yang menjadi tanggung jawabnya

2. Dokumentasi

Dokumen yang digunakan berupa rekaman video dari setiap pelaksanaan plan, do, dan see, dan hasil pekerjaan dan diskusi mahasiswa yang dituliskan dalam Lembar Kerja Mahasiswa (LKM).

Data yang telah diperoleh selanjutnya dianalisis secara kualitatif yang terdiri dari 3 (tiga) tahapan yaitu reduksi data, penyajian data, dan penarikan kesimpulan. Reduksi data difokuskan pada kegiatan mahasiswa yang berhubungan dengan kemampuan kerjasama dan temuan-temuan baru yang menarik dalam pembelajaran. Hasil observasi akan disilangkan dengan dokumen rekaman video dan hasil pekerjaan mahasiswa untuk saling melengkapi agar diperoleh data yang lebih akurat dan valid. Catatan catatan berupa temuan dari dosen-dosen observer juga akan disilangkan dengan hambatan-hambatan yang telah dialami oleh dosen model untuk dianalisis. Hasil analisis kualitatif data-data ini akan menghasilkan sistematika proses belajar yang dilakukan mahasiswa sehingga perkembangan aktivitas kerjasama mahasiswa dapat diidentifikasi.

Pelaksanaan kegiatan lesson study dalam pembelajaran ini, dilaksanakan dengan tiga tahapan, yaitu Plan, Do, dan See. Tahapan tersebut dapat dilihat pada Gambar 1. 


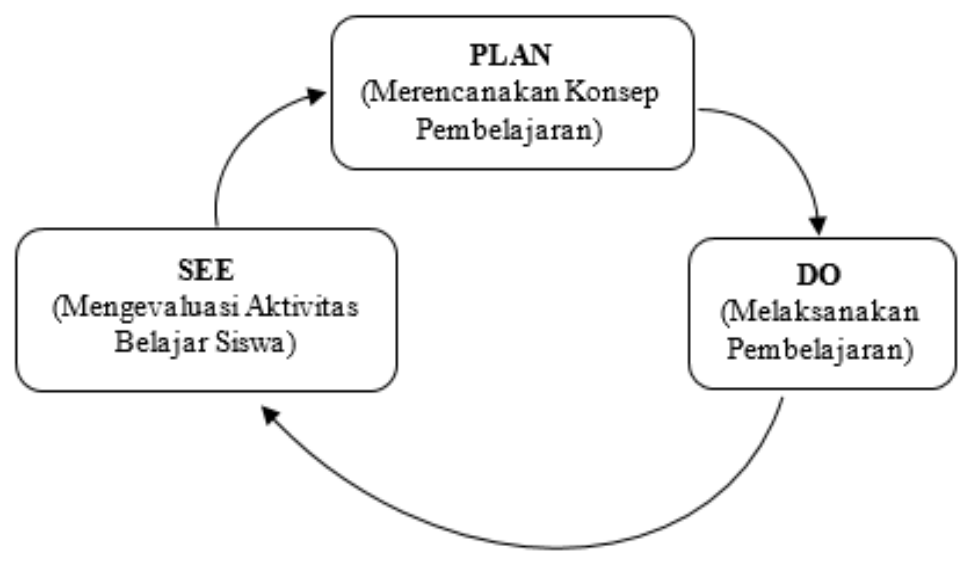

\section{Gambar 1. Tahapan Kegiatan Lesson Study}

Berdasarkan Gambar 1. kegiatan pembelajaran dalam penelitian ini dilaksanakan dengan mengikuti siklus lesson study yang dilaksanakan dalam 2 (dua) siklus. Secara umum (Abizar, 2017:77-80) menguraikan setiap tahapan dari lesson study sebagai berikut.

\section{Perencanaan (Plan) ;}

Tahap perencanaan ini merupakan tahapan awal yang dilakukan oleh tim lesson study. Tim lesson study ini terdiri dari 4 (empat) orang, dimana 1 (satu) orang berperan sebagai dosen model yaitu Annajmi, S.Pd., M.Pd dan 3 orang berperan sebagai observer yang mengamati aktivitas belajar mahasiswa. Adapun observer dalam lesson study ini adalah Gerlan A. Manu, S.T., M.Kom., Vera Dewi Kartini Ompusunggu, S.Pd., M.Pd. dan Intan Kesumawati, S.Pd., M.Pd. Tim lesson study menyusun rencana pembelajaran untuk tercapainya tujuan pembelajaran. Perencanaan yang dilakukan diantaranya dengan mempersiapkan lesson plan (rencana pembelajaran), lembar kerja mahasiswa (LKM), media pembelajaran, strategi pembelajaran dan lembar penilaian dalam hal ini lembar observasi untuk mengamati aktivitas belajar mahasiswa.

\section{Pelaksanaan (Do)}

Tahap pelaksanaan (Do) ini disebut open class. Tahap ini terdapat dua kegiatan utama yaitu: (1) pelaksanaan proses pembelajaran yang dilakukan dosen model sesuai dengan perencanaan yang telah disepakati bersama oleh tim lesson study dan (2) kegiatan pengamatan atau observasi yang dilakukan oleh anggota tim lesson study.

\section{Refleksi (See).}

Tahap refleksi (see) ini merupakan kegiatan diskusi yang dilakukan oleh seluruh tim lesson study (Dosen model dan observer) yang ditujukan untuk memperbaiki pembelajaran pada pertemuan berikutnya. Diskusi dilakukan dengan pemaparan kesan-kesan oleh dosen model selama mengajar baik kelebihan maupun kekurangan dalam melaksanakan tugasnya. Observer menyampaikan semua fakta dan data yang diamatinya mengenai aktivitas belajar mahasiswa, baik aktivitas yang mendukung pembelajaran maupun aktivitas yang tidak berkaitan dengan proses pembelajaran.

Secara keseluruhan pelaksanaan penelitian yang dilaksanakan melalui kegiatan lesson study ini dapat dilihat pada Gambar 2. 
Analisis (Penetapan Masalah dan

Alternatif Pembelaiaran)

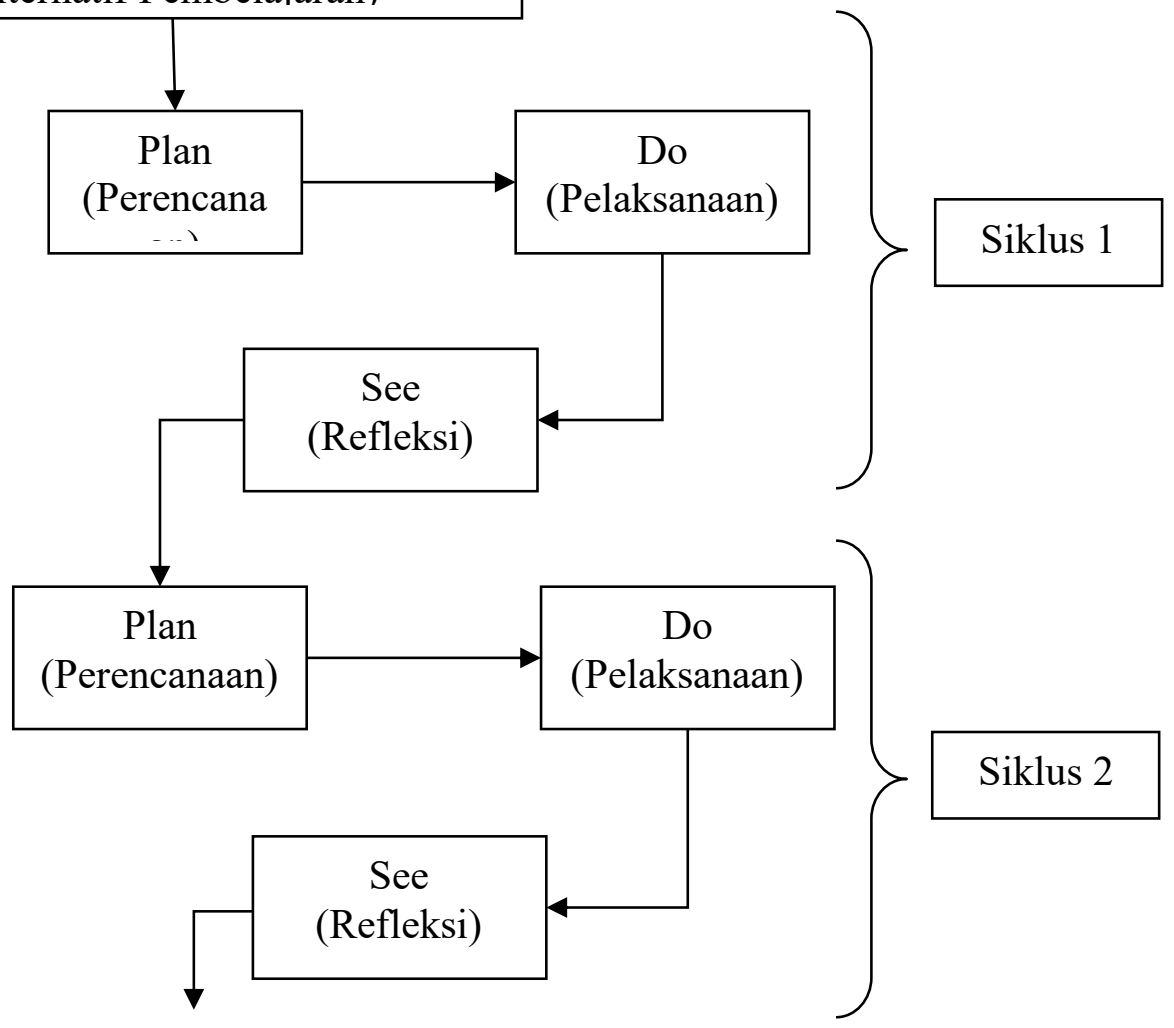

Gambar 2. Alur Pelaksanaan Pembelajaran Berbasis Lesson Study

\section{HASIL DAN PEMBAHASAN}

Kegiatan lesson study ini dilaksanakan dalam dua siklus yaitu dilaksanakan pada hari Jumat tanggal 12 dan 19 September 2018. Hasil dan temuan-temuan selama pelaksanaan lesson study dirangkum berdasarkan indikator-indikator kerjasama. Indikator-indikator tersebut dapat diamati melalui aktivitas yang dilakukan oleh mahasiswa selama pembelajaran. Aktivitas-aktivitas tersebut yaitu mahasiswa melakukan diskusi dengan temannya, bertanya kepada teman/menjawab pertanyaan teman, membantu teman yang mengalami kesulitasn, dan mengerjakan tugas yang menjadi tanggung jawabnya.

Aktivitas kerjasama mahasiswa berdasarkan lembar observasi menggunakan skala likert dalam proses pembelajaran untuk aktivitas kerjasama mahasiswa yang diamati dengan indikator, yaitu mahasiswa melakukan diskusi dengan temannya, bertanya kepada teman/menjawab pertanyaan teman, membantu teman yang mengalami kesulitan, mengerjakan tugas yang menjadi tanggung jawabnya. Adapun hasil pengamatan yang dilakukan oleh pengamat (observer) untuk aspek kerjasama mahasiswa dalam diskusi kelompok dan diskusi kelas, dapat dilihat pada Tabel 1 . 
Tabel 1. Aspek Kerjasama Mahasiswa LS Siklus I

\begin{tabular}{lcc}
\multicolumn{1}{c}{ Kategori } & Frekuensi & Persentase \\
\hline Kurang Baik & 0 & 0 \\
\hline Cukup Baik & 9 & 32,14 \\
\hline Baik & 11 & 39,29 \\
\hline Sangat Baik & 8 & 28,57 \\
\hline \multicolumn{1}{c}{ Jumlah } & $\mathbf{2 8}$ & $\mathbf{1 0 0 \%}$ \\
\hline
\end{tabular}

Tabel 1 menggambarkan kerja sama mahasiswa dalam diskusi kelompok, terlihat bahwa kerjasama mahasiswa rata rata berada pada kategori Baik, yaitu 39,29\%, dan pada kategori sangat baik, yaitu $28,57 \%$. Hal ini berarti kerjasama mahasiswa dalam diskusi kelompok sudah berjalan dengan baik, namun demikian persentase mahasiswa pada kategori cukup baik terdapat 32,14\%. Hal ini berarti terlihat bahwa secara umum mahasiswa sudah bekerjasama dalam kelompok, namun masih ada terdapat beberapa mahasiswa yang belum terlibat dalam diskusi.

Aktivitas kerjasama mahasiswa dalam pembelajaran LS siklus II, berdasarkan hasil pengamatan observer terhadap aktivitas belajar mahasiswa dapat dideskripsikan pada Tabel 2.

\section{Tabel 2. Aspek Kerjasama Mahasiswa LS Siklus II}

\begin{tabular}{lcc}
\hline \multicolumn{1}{c}{ Kategori } & Frekuensi & Persentase \\
\hline Kurang Baik & 0 & 0 \\
\hline Cukup Baik & 3 & 10,71 \\
\hline Baik & 15 & 53,57 \\
\hline Sangat Baik & 10 & 35,71 \\
\hline \multicolumn{1}{c}{ Jumlah } & $\mathbf{2 8}$ & $\mathbf{1 0 0 \%}$ \\
\hline
\end{tabular}

Tabel 2 menggambarkan kerja sama mahasiswa dalam diskusi kelompok, terlihat bahwa kerjasama mahasiswa rata rata berada pada kategori Baik, yaitu 53,57\%, dan pada kategori sangat baik, yaitu 35,71\%. Hal ini berarti kerjasama mahasiswa dalam diskusi kelompok sudah berjalan dengan baik, dimana aktivitas kerjasama mahasiswa pada kategori cukup baik terdapat 10,71\%. Hal ini berarti mahasiswa memiliki aktivitas kerjasama yang baik dalam kelompok, dimana setiap anggota kelompok terlibat aktif dalam diskusi kelompok, maupun diskusi kelas.

Berdasarkan hasil temuan temuan observer terdapat beberapa aktivitas kerjasama mahasiswa dalam kelompok yang mendukung proses pembelaajran dan yang tidak mendukung proses pembelajaran. Adapun aktivitas aktivitas kerjasama temuan temuan observer, diantaranya diuraikan sebagai berikut.

Kelompok kelompok berdiskusi engan baik, dimana masing masing anggota kelompok bisa terlibat aktif dalam berdiskusi dengan teman dalam kelompok, adanya mahasiswa bertanya kepada teman dalam kelompok dan teman yang lain menjawab pertanyaan temannya, mahasiswa saling membantu teman dalam kelompok yang mengalami kesulitasn, dan mengerjakan tugas yang menjadi tanggung jawab kelompok secara bersama. 
Beberapa temuan observer pada catatan lembar observasi, diperlihatkan bahwa kelompok yang sudah bekerja sama dengan anggota kelompok dimana setiap kelompok berdiskusi dan mampu menjelaskan maksud materi yang disajikan di LKM kepada teman kelompoknya, misalnya mahasiswa dengan nomor 19 menjelaskan kepada mahasiswa nomor 24, 19, 25 dan 17. Selain itu mahasiswa juga aktif untuk menjawab pertanyaan dan menuliskan di papan tulis, yaitu mahasiswa nomor 4 , sedangkan mahasiswa nomor 15 dan 29 memberikan tanggapan dengan antusias menjawab pertanyaan dari guru dan merespon presentasi dari kelompok lainnya. Berikut beberapa gambar aktivitas kerjasama mahasiswa dalam diskusi.

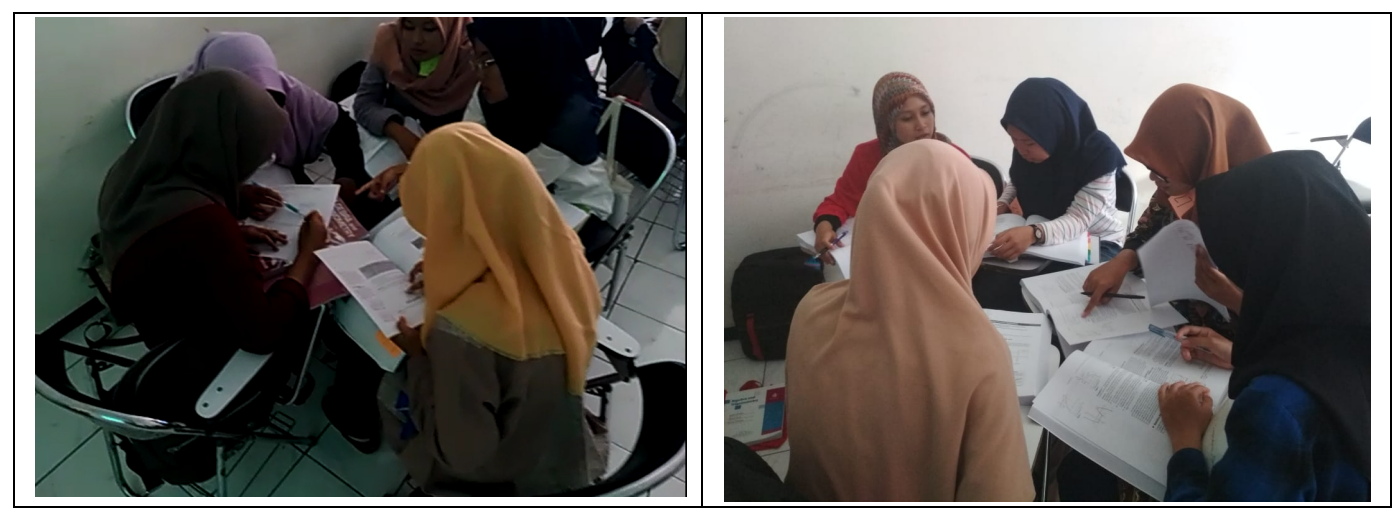

\section{Gambar 1. Aktivitas Kerjasama dalam Diskusi Kelompok}

Hasil pengamatan observer juga memperlihatkan bahwa adanya mahasiswa yang belum belajar dengan baik dalam diskusi kelompok, adanya mahasiswa nomor 23 dan 29 bercerita dengan teman kelompoknya diluar dari topik materi yang dibahas. Ketika waktu diskusi kelompok pada 10 menit terakhir kelompok yang anggota nya mahasiswa nomor 14,13,21, dan 16 dan 18, 19 dan 24 masih belum selesai berdiskusi. Hal ini berarti mahasiswa belum memiliki tanggung jawab yang baik dalam berdiskusi kelompok, namun temuan ini tidak ditemukan pada kegiatan LS siklus 2. Mahasiswa dalam setiap kelompok bisa mamanfaatkan waktu dengan baik untuk bekerjasama mendiskusikan topik yang dibahas dalam LKM.

Pelaksanaan pembelajaan pada siklus kedua dari kegiatan LS ini mahasiswa terlihat memiliki aktivitas kersama yang baik, hal ini selain terlihat dari lembar observasi yang ada, juga dari rekaman video yang diambil dalam proses pembelajaran. Berikut ditampilkan beberapa cuplikan aktivitas mahasiswa dalam diskusi kelompok. 


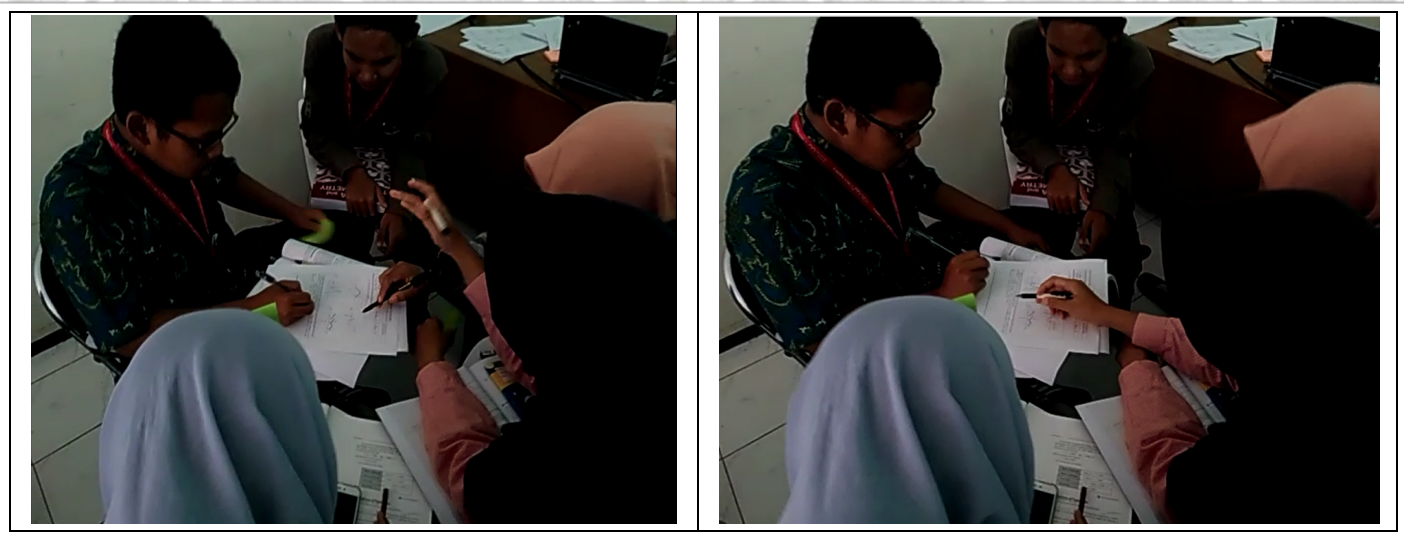

Gambar 2. Aktivitas Diskusi Mahasiswa dalam Kelompok

Gambar 2, menunjukkan mahasiswa berinteraksi bersama anggota kelompoknya dalam melakukan diskusi mahasiswa sedang memberikan penjelasan kepada teman satu kelompoknya dan teman yang lain juga memberikan tanggapan atas apa yang sedang didiskusikan. Hal ini menjadikan tugas yang diberikan dalam diskusi kelompok dapat diselesaikan dengan baik, dimana mahasiswa antusias untuk maju kedepan untuk mempresentasikan hasil kelompoknya, begitu juga ketika diberikan soal latihan, masing individu juga sangat bersemangat untuk menuliskan jawabannya di papan tulis, dengan demikian mahasiswa sudah bisa memahami materi dengan baik melalui kerjasama yang baik pula dalam diskusi kelompok. Aktivitas ini dapat dilihat dari rekaman video yang diambil dalam proses pembelajaran, yaitu

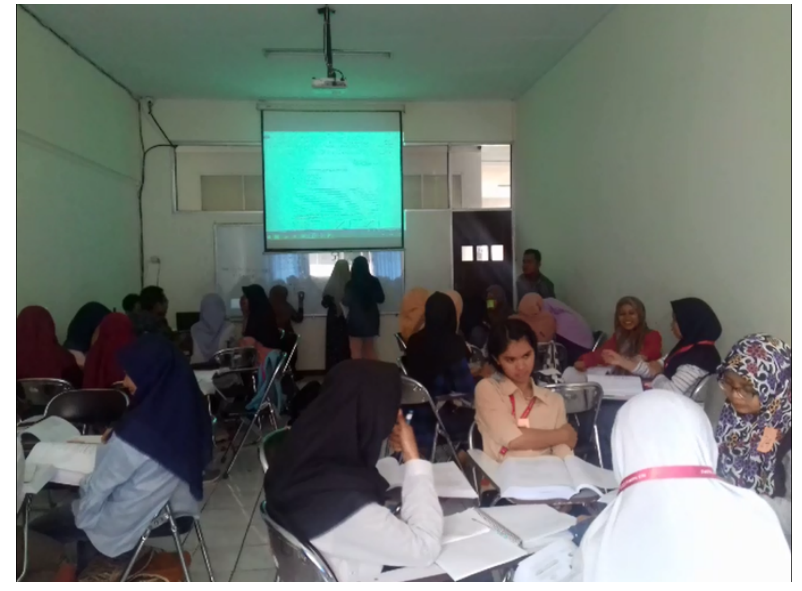

\section{Gambar 3. Mahasiswa Menuliskan Jawaban di Papan Tulis}

Temuan lain dari catatan observer adalah ketiga tahap make a match, mahasiswa aktif berinteraksi untuk menemukan pasangan yang sesuai dengan soal dan jawaban yang diperoleh masing masing individu, begitu juga ketika diminta untuk menuliskan jawaban di papan tulis hampis semuanya mau maju kedepan. Hal ini dibuktikankan dengan rekaman video yang diambil dalam proses pembelajaran pada gambar 4. 


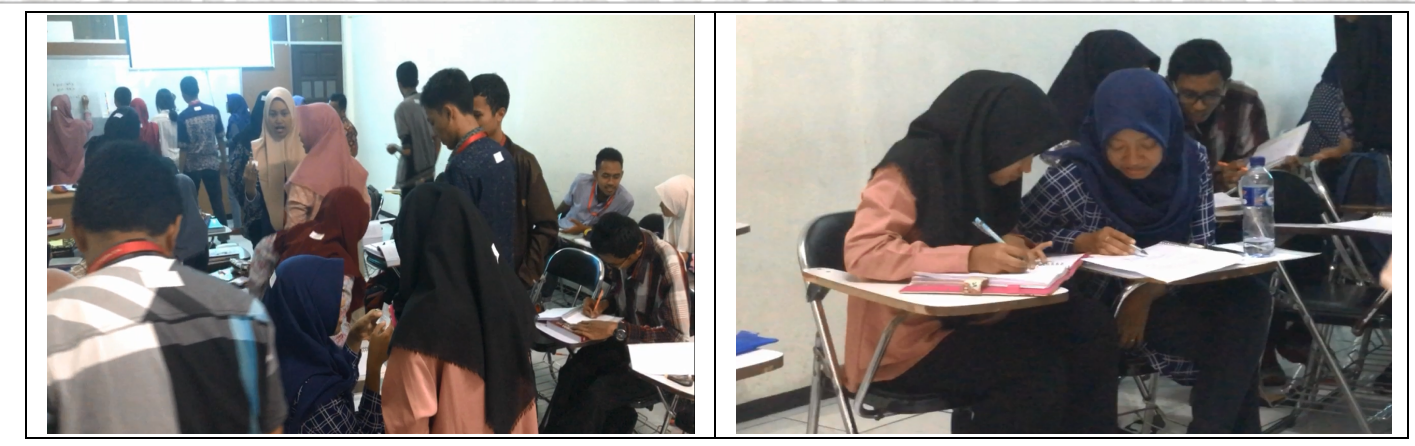

Gambar 4. Mahasiswa Mencari Pasangan dan Diskusi Bersama Pasanganya

Gambar 4 menunjukkan mahasiswa antusias sekali untuk menemukan pasangan dan melakukan kerjasama dengan diskusi bersama pasangan yang telah ditemukan. Gambar a memperlihatkan bahwa pasangan yang sudah menemukan pasangannya dan melakukan diskusi langsung menuliskan jawabannya di papan tulis, walaupun masih ada mahasiswa yang belum menemukan pasangannya dan masih sedang berdiskusi mengenai soal latihan yang mereka peroleh.

Berdasarkan uraian hasil temuan observer tersebut dapat digambarkan bahwa model pembelajaran kooperatif make a match telah mampu menjadikan mahasiswa untuk berinteraksi bersama teman kelompok dan bisa melatih kemampuan berpikir matematisnya. Hal ini senada dengan yang dinyatakan oleh Lie, (2003:27) bahwa pembelajaran kooperatif didasarkan atas falsafah homo homini socius, falsafah ini menekankan bahwa manusia adalah mahluk sosial, model make and match melatih siswa untuk memiliki sikap sosial yang baik dan melatih kemampuan siswa dalam bekerja sama disamping melatih kecepatan berfikir siswa. Penelitian lain juga yang dilakukan oleh Jaelani, Kusno, dan Subekti, 92013) menyimpulkan bahwa bahwa pembelajaran kooperatif mata kuliah Dasar Proses Pembelajaran Matematika yang telah dirancang melalui lesson study dapat membantu perkembangan aktivitas kerjasama mahasiswa.

\section{KESIMPULAN DAN SARAN}

Berdasarkan hasil pengamatan para observer, dan uraian hasil penelitian memperlihatkan bahwa pembelajaran yang telah direncanakan oleh dosen model dan para dosen observer yaitu pembelajaran menggunakan pembelajaran kooperatif make a match telah dapat memunculkan aktivitas-aktivitas kerjasama mahasiswa yang dapat dilihat perkembangannya dari rekaman video. Hasil dan pembahasan dalam penelitian ini, sehingga dapat disimpulkan bahwa pembelajaran kooperatif make a match dalam pembelajaran matematika melalui lesson study dapat membantu aktivitas kerjasama mahasiswa menjadi lebih baik.

\section{UCAPAN TERIMAKASIH}

Ucapan terimakasih disampaikan kepada Universitas Negeri Malang dan Direktorat Jenderal Sumber Daya IPTEK dan DIKTI, Kementerian Riset Teknologi dan Dikti yang 
telah memberikan bantuan dana, waktu dan tempat pelaksanaan penelitian ini melalui kegiatan Program Magang Dosen 2018.

\section{DAFTAR PUSTAKA}

Anthony, G. \& Walshaw, M. (2009). Characteristics of effective teaching of mathematics: A view from the west. Journal of Mathematics Education, 2(2), 147164

Asnawati, R. (2006). Meningkatkan Aktivitas, Motivasi, dan Hasil Belajar Melalui Pendekatan Kontekstual dengan Model Kooperatif Tipe STAD (Studi di Kelas IV B SDN 2 Labuhanratu Bandar Lampung. Prosiding BKS PTN Wilayah Barat Bidang Pendidikan. p 83

Barkley, E. E., Cross, K. P., \& Major, C. H. (2012). Collaborative Learning Techniques. Bandung: Nusamedia.

Garfield, J. 2006. Exploring the Impact of Lesson study on Developing Effective Statistics Curriculum. University of Minnesota. (Online) (http://iaseweb.org/documents/papers/icme10/Garfield.pdf,Diakses)

Davis, K., \& Newstrom, J. W. (1996). Perilaku Organisasi. Jakarta: Erlangga.

Hamalik, Oemar. 1999. Kurikulum dan Pembelajaran. Jakarta: Bumi Aksara

Kennedy, dkk., Guiding Children's Learning of Mathematics (USA: Thompson Wadsworth, 2008), h. 70-71;

Purwadarminta. (2007). Kamus Besar Bahasa Indonesia. Jakarta: Balai Pustaka.

Saito, E., Imansyah, H., Ibrohim. 2005. Penerapan Studi Pembelajaran (Lesson Study) di Indonesia: Studi Kasus dari IMSTEP. Jurnal Mimbar Pendidikan, (Online)3 (24):hal. 24-32.

Slavin, R.E. (2006). Cooperative Learning Theory, Research, and Practice. Second Edition. America: Allyn and Bacon

Stein, S. J., \& Book, H. E. (2004). Ledakan EQ 15 Prinsip Dasar Kecerdasan Emosional Meraih Sukses. Bandung: Kaifa

Stigler, J. \& Hiebert, J. 1999. The Teaching Gap. Best ideas from the world's teachers for improving education in the classroom. New York: Free Press. (Online) (http://readingfirst.scoe.net/document s/LEASession3.pdf)

Utami, B et al. 2011. Penerapan Pendekatan Konstruktivisme Melalui Model Pembelajaran Think Pair Share (TPS) dalam Kegiatan Lesson Study untuk Meningkatkan Kualitas Proses dan Hasil Belajar Strategi Belajar-Mengajar. Jurnal Inovasi Pendidikan Jilid 12 Nomor 1 p 1 - 18. 